Association for Information Systems AIS Electronic Library (AISeL)

2000

\title{
Internet Transactions and Physical Logistics: Conflict or Complementarity?
}

\author{
Ashok Ranchhod \\ Southampton Business School, ashok.ranchhod@solent.ac.uk \\ Calin Gurau \\ Southampton Business School \\ Ray Hackney \\ Manchester Metropolitan University, r.hackney@mmu.ac.uk
}

Follow this and additional works at: http://aisel.aisnet.org/amcis2000

\section{Recommended Citation}

Ranchhod, Ashok; Gurau, Calin; and Hackney, Ray, "Internet Transactions and Physical Logistics: Conflict or Complementarity?" (2000). AMCIS 2000 Proceedings. 241.

http://aisel.aisnet.org/amcis2000/241

This material is brought to you by the Americas Conference on Information Systems (AMCIS) at AIS Electronic Library (AISeL). It has been accepted for inclusion in AMCIS 2000 Proceedings by an authorized administrator of AIS Electronic Library (AISeL). For more information, please contact elibrary@aisnet.org. 


\title{
Internet Transactions and Physical Logistics : conflict or complementarity ?
}

\author{
Cãlin Gurãu and Ashok Ranchhod, Southampton Business School, <ashok.ranchhod@ solent.ac.uk> \\ Ray Hackney, Manchester Metropolitan University, <r.hackney@mmu.ac.uk>
}

\begin{abstract}
This paper argues that the whole company, and the market in which it operates, can be regarded as a series of linkages and relationships, and the company's operating efficiency can be seen to depend upon how well these connections work. It notes that if the system can be made to flow smoothly, at minimum cost, than the chances are that the overall company performance, measured by any criteria, could be high (complimentarity?). In practice, however, it is very common to find bottlenecks and poor integration between different parts of this system, resulting in unsatisfactory performance (conflict?). In order to identify the effects of the Internet on the physical logistic system, the WWW sites of 500 commercial companies were randomly selected, accessed and studied during November 1999.
\end{abstract}

\section{Introduction}

Over the last few years, the science of marketing has gradually extended its frontiers. The emphasis on marketing as a means of creating customers, identifying and anticipating market needs, whilst valid in itself, has proved to be too narrow. This is because the definition of marketing goals and the implementation of marketing strategies inevitably have some implications for other areas within the corporate system. If the interfaces between marketing and other functional areas in the company are not given enough attention, decisions in one area may produce disturbances elsewhere in the system that can impair total company performance. This tendency is very noticeable in the interface between marketing and distribution. A recognition of the key role that distribution can play in the company's marketing effort can be the first step to a new, integrative approach to the management and supply of markets, based upon the development of logistics, or a total 'systems' approach to the company's activities. The main emphasis of the logistics is on systems It suggests that the materials-flow activity in a company has such an extensive and pervasive impact on different departments that it should be considered as a system. Thus the activities of marketing, production, communication and distribution departments need to be harmonised in order to increase the overall efficiency of a company. The principal task of physical distribution is to ensure that products are available at the right places at the right time in the right quantities to satisfy customer demand (Christopher et al; 1979).

\section{Transaction Processes on the Internet}

The use of the Internet has become increasingly important in the last five years, particularly in industrialised countries in which the cost of accessing and building an Internet site is relatively low (Cronin, 1995, 1996a; Watson and Zinkhan, 1997; Clemente, 1998). The Internet has many potential uses, depending on the objectives and capabilities of the user (The Economist, 1998). It can be (1) a source of information, (2) a communication tool and (3) a distribution channel for products and services. The new developments in the field of multimedia software have increased the range of information than can be transmitted, which can now be expressed in the form of printed text, image, sound, or a combination of all these (Watson et al., 1998). Taking into consideration the advantages of speed, interaction and flexibility, it is easy to understand why the Internet is considered as a revolutionary tool for the development of commercial transactions. Many innovative companies have made attempts to transfer a part of their marketing activities onto the Internet, in order to benefit from the advantages offered by this unique system of communication (Ghosh, 1998; Watson et al., 1998). Many authors have analysed the impact of the Internet on the marketing strategies implemented by companies (Ellsworth \& Ellsworth, 1995,96; Sterne, 1995; Quelch \& Klein, 1996; Hamill \& Gregory, 1997).

The efficiency of the Internet is higher for the companies whose value-added contribution is concentrated primarily in the informatic side of their products (Benjamin and Wigand, 1995; Cameron, 1997; Watson and Zinkhan, 1997). There is a general trend in all areas of human activity to create more value through information, but this is especially true for the high-tech companies (informatics, biotechnology, electronics). Despite existing problems (Hoffman et al., 1997; Clemente, 1998) related with the ease of access and overall security of electronic transactions, predictions are extremely optimistic. The range and the volume of products sold on-line will constantly increase in the future, expanding the size and value of the electronic market (Cameron, 1997; De Kare Silver, 1998).

Considering the relationship between Internet commerce and physical logistic systems, the following hypotheses can be formulated:

H1. Most of the Internet business transactions still depend on a physical logistic system. 
H2. The on-line offers will be primarily directed to the national/regional markets which have a well developed logistic infrastructure.

H3. The development of on-line commerce has to be complemented by the implementation of a physical logistic system.

H4. The companies which already have a physical logistics system are in a good competitive position to successfully exploit the Internet business channel.

In order to be selected and studied, a company had to have an active business presence on the Internet - WWW site and have a commercial activity - to offer and sell products on-line. The nationality of the companies confirmed the predominance of US based companies on the Internet. 399 of the firms were US-based (79.8\%), followed at a long distance by UK based companies - 33 (6.6\%), Australia and Canada with 15 (3\%), Taiwan with $10(2 \%)$, Japan, Italy and Singapore with $5(1 \%)$, and finally, France and Germany with $4(0.8 \%)$.

The place and the importance of the physical logistic system in relation with Internet commerce was evaluated considering the distribution strategies implemented by the companies studied. The importance of the physical distribution system ranges from low for the companies which have implemented an on-line distribution system, medium for the companies using direct shipping or a distribution network of agents and dealers, and high for the companies which distribute the products through their own system of subsidiaries.

In the case of on-line distribution, the importance of the physical logistic system is minimal. This strategy can be implemented only for digital products, which can be transmitted through electronic connections. However, even in this case the company should be concerned about the quality and reliability of the electronic system. Some countries have not yet implemented fiber optics phone lines, and the capacity to transmit large amount of information can be impaired. On the other hand, the final receiver/customer of the digital product must have the necessary software and hardware to download and store the product without errors. In some cases, the specialised software needed to access or process the digital product is provided free of charge by the selling company and can be downloaded from its Internet site. The companies using a direct shipping distribution strategy, or a network of agents and dealers are obliged to use the physical distribution system owing to the non-digital nature of their products. However, they try to minimize the number of physical assets which they own and manage, subcontracting the distribution services from other specialised companies.
When direct shipping is offered, the customer can access the WWW site of the selling company to obtain all the necessary information about the desired product and order it on-line. In the second stage, the company ships the purchased (or the selected) product directly to the customer. If the client is another company or organization, the distribution will be considered a direct export, in which other intermediaries can be indirectly involved (exporting agencies, transportation and insurance companies). For individual clients, the companies normally use the services of international delivery companies (UPS, USPS, Federal Express, TNT, etc.). Depending on the urgency of request, different options of speed delivery can be chosen, obviously, with a differentiated level of price.

When the direct shipping option is not possible (either because of the volume of the offered product or because of the additional services required for the installation of the product to the buyer), a company uses a network of agents and dealers who also provide the physical logistic system for the distribution of products. In some cases the logistic operations are sub-contracted by the selling company from other specialised firms, the agent/dealer acting only as a commercial representative of the selling company. The distribution through subsidiaries offers the highest degree of control and of responsibility over the physical logistic operations. The company owns warehouses, commercial outlets, and sometimes even transportation facilities (ships, trucks, plains, etc.). However, some logistic operations can be subcontracted on a permanent or temporary basis (as, for example, when a company has to deal with a special order or an increase in demand). The efficiency of the distribution operations can be improved significantly through an Electronic Data Interchange (EDI) system, which can be implemented between the selling company and its partners/subsidiaries. The logistic operations can be correlated and managed in such a way to provide a quick and problem-free transfer of the material product between the selling company and the final customer.

Considering that only $47 \quad 9.4 \%$ of the surveyed companies) have implemented an on-line distribution system, confirms the hypothesis that:

\section{H1. Most of the Internet business transactions still depend on a physical logistic system.}

Most of the researched markets are targeting their offer to the developed countries $(91 \%)$, either at domestic (36\%), regional (28\%) or international (27\%) level. Only 45 (9\%) of the surveyed companies are offering their products on a global basis, targeting both developed and developing countries. The possible problems related with the physical logistic operations in a country which does not have a well 
developed logistic infrastructure represent an important factor in the selection of target markets for on-line offers.

This confirms the hypothesis that:

H2. The on-line offers will be primarily directed to the national/regional markets which have a well developed logistic infrastructure.

Considering the qualitative nature of the third and fourth hypothesis, two mini cases studies have been developed in order to investigate in-depth the relationship between online commerce and physical distribution systems at two successful companies: Tesco and Amazon.com.

\section{Mini Case: Amazon.com}

Amazon.com opened its virtual doors in July 1995 with a mission to use the Internet to transform book buying into the fastest, easiest, and most enjoyable shopping experience possible. Today, Amazon.com is the place to find and discover anything you want to buy online. The company has more than 17 million customers in more than 160 countries that have made Amazon.com the leading online shopping site. The company offers Earth's Biggest Selection of products, including free electronic greeting cards, online auctions, and millions of books, CDs, videos, DVDs, toys and games, and electronics. As part of its efforts to provide the best shopping experience for customers, Amazon.com provides secure credit-card payment, personalised recommendations, streamlined ordering through 1-Click technology, and hassle-free auction bidding with Bid-Click.

Amazon.com operates two international Web sites: www.amazon.co.uk in the United Kingdom and www.amazon.de in Germany. Amazon.com has entered the European market in October 1998 with the simultaneous launch of new Web sites in Germany and the United Kingdom. These sites make available to Europeans a vast selection of goods, guaranteed safety of transactions, unparalleled convenience, and electronic gift certificates for worry-free gift giving. In addition, the two sites have significantly reduced the cost of and shipping time for thousands of U.S. titles, thanks to a large supply of the most popular U.S. titles ready for immediate shipment from the U.K. and Germany. In addition, thousands of other U.S. titles will be delivered much sooner from Amazon.com facilities in the United States. The Internet expansion of Amazon.com over the last 5 years has been correlated with the development of its physical logistic system. Amazon.com owns an international network of warehouses and customer services centres, located in its main target markets : USA, UK and Germany.
There are seven warehouses owned by Amazon.com in USA, located in Seattle (Washington), NewCastle (Delaware), Fernley (Nevada), Coffeyville (Kansas), Campbellsville and Lexington (Kentucky) and McDonough (Georgia). The last five warehouses were established in 1999, fact which demonstrate the rapid expansion of the company's business operations. An integral part of the firm's effort to enhance customer's experience, these stateof-the-art facilities maintain quality control over the packaging and shipping of products. Using the company's data system, not only can orders from multiple publishers be shipped at one time, but books can be packaged with CDs and/or videos also ordered. In the process, Amazon.com employees can check for defective goods, like for example cracked CD packaging. The warehouses are located with purpose (Sauders, 1999). Delaware, where the firm has set up its second warehouse, does not have a sales tax. Nevada was chosen to speed delivery on the West coast. Nevada is also a free-tax state, and Fernley is located near Reno, Nevada, close enough to the huge California population, but just outside the state's tax-collection borders. The Kansas and Kentucky establishments were opened to access the key markets from the Midwest and Southeast United States more quickly. Amazon.com's Georgia distribution center will play an integral role in the company's overall global logistics strategy and is part of the company's effort to develop a significant distribution infrastructure to meet long-term growth and provide Amazon.com customers nationwide and around the world with fast, reliable shipping that comes directly from the company.

In Europe, Amazon.com owns warehouses in UK (Slough and Marston Gate) and in Regensburg Germany. These warehouses/distribution centres are complemented by seven customer service centres, located in Seattle and Tacoma (Washinghton), Grand Forks (North Dakota), Huntington (West Virginia), Slough (England), Regensburg (Germany) and The Hague, Netherlands. In organising and managing its logistic system, Amazon.com collaborates with ProLogis (www.amazon.com), who is the largest US based global provider of integrated distribution services, with more than 1,500 distribution facilities owned throughout North America and Europe. As the main distribution system needed by Amazon.com is direct mail shipping, the company primarily uses the services offered by DHL. Order information is downloaded into two DHL Easyship systems - comprehensive kits installed at Amazon sites to produce airway bills, pro forma invoices, and management reports - so that shipments can be dispatched and collected by DHL. The main philosophy of Amazon.com has been to align distribution and logistics with strategic plans (Saunders, 1999).

The complementary expansion of Amazon.com's Internet business and its physical logistic system represents a good example of an integrated commercial strategy. The 
company understands that the road to long-term success lies not only in the flow of information, but also in the quality and the speed of physical delivery. This case study supports the hypothesis:

H3: The development of on-line commerce has to be complemented by the implementation of a physical logistic system.

For the hypotheses to be tested fully a large statistical sample would be necessary.

\section{Mini Case: Tesco}

Tesco is Britain's largest food retailer and has been leading the trial and experimentation of electronic shopping in its sector. Its web site is one of the most frequently visited by the UK consumer base and it has been steadily building sales. In 1998 Tesco has extended its on-line shopping service, called Tesco Direct throughout London. Its Internet superstores offers customers the ability to purchase any of the 20,000 product lines typically available in its stores (de KareSilver, 1998). At present there are two ways you can shop with Tesco Direct, on-line or off-line (www.tesco.co.uk). Off-line shopping involves the use of Tesco's Homeshopping software. The prospective buyer can order a free Homeshopping CD when he/she registers with Tesco Direct. This allows customers to connect to the Internet to get the latest product and price details, then disconnect to shop off-line and then to connect again only to send an order.

On-line shopping means selecting the goods 'live' through the Tesco Direct site. Every purchase made through Tesco Direct is automatically stored in the customer's favourites list to make future shopping faster and easier. The connection is secured by using encryption. Next day delivery is the usual arrangement but shoppers can also order goods up to 28 days in advance. When ordering the goods, the customers can also select a two-hour delivery window that suits them best. The goods are chosen on the day of delivery by a specially trained team of personal shoppers and delivered with temperature controlled vans. The secret behind the success of Tesco Internet Shopping Service is an extremely well organised logistic system. Its purpose is to ensure that Tesco stores have the right products delivered against agreed delivery schedules and in good condition, enabling the stores to provide a consistently high level of customer service. Tesco products are sent to stores from distribution centres around the country. Tesco runs 13 centres and a further six centres are run for Tesco by contractors. A typical centre covers 300,000 square feet and handles some 50 million units a year. The centres work around the clock, seven days a week, providing 2,500 deliveries daily, amounting to 19 million cases per week. Tesco employs 6,800 people in distribution (excluding the staff at the contractor-run centres), and has about 1,000 truck units and 2,000 trailers in its national vehicle fleet.

The key to the distribution system's ability to supply each store's needs are the advanced use of IT at all stages of the distribution system. Information from stores about their sales and requirements is sent to Tesco Head Office and from there to the distribution centres. The centres run a computer system that has been specially designed to fit with Tesco working practices and to maximise efficiency. Computerised information arrives via printers in the warehouse offices. The system feeds this information directly to the staff on the warehouse floor via radio links mounted on the fork-lift trucks. The system helps to control the movement of stock and the activity of staff. Thus when a person has finished a particular job, the computer decides which would be the most efficient job to allocate next to that person, based on his or her current position in the warehouse. In the past, distribution operations have been slowed down at peak times by the need for product identification and purchase-order matching. Currently, each goods-in checker is equipped with a scan gun which can scan the outer case code of each product and radio the information back to the Head Office computer, which matches a delivery with its purchase order in an instant. As well as easing bottlenecks, this system enforces accurate outer case coding, which Tesco believes to be essential to future developments in its distribution system.

Tesco uses specialised delivery vehicles which have three separate compartments, each with an independent temperature control in the range $-25^{\circ} \mathrm{C}$ to $+12^{\circ} \mathrm{C}$. This allows a wide variety of goods to be transported to the same store on the same lorry. In order to gain the most efficient use of a lorry, the insulating bulkheads that divide the compartments are movable so that the sizes of the compartments can be varied according to the load. The bulkheads can also be removed entirely, to provide one or two compartments only. This capability is important, as there are five different temperature bands for the transportation of different groups of foods. Integrating the computer technology with its existent physical logistic system, Tesco is actively putting itself in a prime position to benefit from increasing electronic shopping interest. The company is establishing itself in the customers' eyes as being the leading edge exponent of internet shopping and will thus be best able of all competitors to effectively respond and see through the inevitable evolution of its existing retail estate. Operationally there is no doubt that retailers could achieve great success as pioneers and major distributors in an electronic environment (de KareSilver, 1998). They have years of retail experience. They are well placed in the present value chain. They can 
enhance their market position and capabilities in the Internet era by 'value networking' They can bring a select range of partners and experts to help them realise their goals. The solution to channel conflicts lies in their own hands.

The implementation and organisation of Tesco Direct is a good example of a successful attempt to integrate on-line shopping into an existing distribution system, and supports the hypothesis :

H4. The companies which already have a physical logistic system are in a good competitive position to successfully exploit the Internet business channel.

\section{Conclusion}

Internet commerce cannot eliminate the need of physical logistic systems, if fact, it could be argued that it increases their importance for certain categories of goods. The nature of the distribution system actually changes, with the development of more and smaller nodes as one to one customer relationships begin to develop. The Internet itself, can be used as a distribution channel only for a limited range of goods, which can be stored, processed and transmitted in a digital format. However, the Internet can be used to manage the informational side of any transactions, e.g. exchange of information, inventories, tracking deliveries and providing in-line customer service. This is a novel situation which did not exist in the mid nineties of the last century. The Internet cannot eliminate or replace the classical functions performed within a marketing channel, but can restructure them. The flow of information between the company and its suppliers, partners and customers, can be efficiently managed over the Internet, reducing the costs and increasing the speed and the quality of data transfer. It is clear that a virtual company should organise a complementary physical logistic system in order to distribute material products to its clients, if its products are non-digital. On the other hand virtual service companies such as QXL.com and Lastminute.com rely on information distribution and as such their broking ability largely relies on the development of an excellent software support system.

Many specialists (Birch et al., 2000; de Kare-Silver, 1998; Markhan, 1998) suggest that the future will be dominated by Internet commerce., This over optimistic vision has to be tempered by practical considerations. The physical logistic system was, is and will remain an essential element of general business strategy, providing both challenges and opportunities for companies operating on the Internet .

\section{References}

Alba, J., Lynch, J., Weitz, B., Janiszewski, C., Lutz, R., Sawyer, A. and Wood, S. (1997) Interactive Home Shopping: Consumer, Retailer, and Manufacturer Incentives to Participate in Electronic Marketplaces. Journal of Marketing 61(3), 38-51.

Anderson, C. (1997) Electronic Commerce. The Economist, The Economist Survey, 343 (8016), 10 May, after page 72 .

Benjamin, R. and Wigand, R. (1995) Electronic Markets and virtual value chains on the Information Superhighway. Sloan Management Review, 36(2), 62-72.

Birch, A., Gerbert, P., Schenider, D, OC\&C and The Mckenna Group (2000) The age of E-Tail, Capstone Publishing, Oxford.

Cameron, D. (1997) Electronic Commerce. The New Business Platform for the Internet, Computer Technology Research Corp., Charleston.

Christopher, M.C., Schary, P.B. and Skjøtt-Larsen, T. (1979) Customer Service and Distribution Strategy, Associated Business Press, London.

Christopher, M. (1979) Logistics; the total distribution concept, in Managing International Distribution, Felix Wentworth and Martin Christopher eds., Gower Press, Farnborough, pp. 3-13.

Clemente, P. (1998) The state of the Net. The New Frontier, Graw Hill, New York.

Cronin, M.J. (1994) Doing Business on the Internet, Van Nostrand Reinhold, New York.

Cronin, M.J. (1995) Doing More Business on the Internet, Van Nostrand Reinhold, New York.

Cronin, M.J. (1996a) Global advantage on the Internet, Van Nostrand Rienhold, New York.

Cronin, M.J. (1996b) The Internet Strategy Handbook: Lessons from the New Frontier of Business, Harvard Business School Press, Boston.

De Kare-Silver, M. (1998) E-Shock, Macmillan Business, London.

Ellswoth, J.H. and Ellsworth, M.V. (1995) The Internet Business Book, John Wiley, New York.

Ellswoth, J.H. and Ellsworth, M.V. (1996) Marketing on the Internet - Multimedia Strategies for the WWW, John Wiley, New York.

Ghosh, S. (1998) Making Business Sense on the Internet. Harvard Business Review 76(2), 127-35.

Hamill, J. and Gregory, K. (1997) Internet Marketing and the Internationalisation of UK SMEs. Journal of Marketing Management 13(1-3), 9-28.

Hoffman, D.L., Novak, T.P. and Chatterjee, P. (1997) Commercial Scenarios for the Web: Opportunities and Challenges, in Readings in Electronic Commerce, Ravi Kalakota and Andrew B. Whinston (eds.), (AddisonWesley, Reading), pp. 29-53.

Kline, D. (1995) 'Friction-Free' Foolishness \{URL: http://www.hotwired.com /market/95/37/ index1a.html \}. 
Kotler, P. (1997) Marketing Management, 9th edition, (Prentice Hall, Englewood Cliffs, NJ).

Jones, R. (1994) Digital's World-Wide Web Server: A Case Study, Computer Networks and ISDN Systems, 27(2) (November), 297-306.

La Londe, B.J. and Zinszer, P.A. (1976) Customer Service: meaning and measurement, National Council of Physical Distribution Management.

Maddox, K. with Blankenhorn, D. (1998) Web Commerce. Building a Digital Business, John Wiley \& Sons, New York.

Markham, J.E. (1998) The Future of Shopping, Macmillan Business, Basingstoke.

Marchant, B. (1996) Distribution: A practical guide to planning and operation, Kogan Page, London.

McKinnon, A.C. (1989) Physical Distribution Systems, Routledge, London.

Perreault, W.D. and Russ, F.A. (1976) Physical Distribution Service in Industrial purchase decisions, Journal of Marketing, 40, pp. 3-10.

Poon, S. and Jevons, C. (1997) Internet-enabled international Marketing: A Small Business Network Perspective. Journal of Marketing Management, 13(1-3), 29-41.
Porter, M. and Millar, V. (1985) How information gives you competitive advantage. Harvard Business Review 63(4), 149-60 .

Quelch, J.A. and Klein, L.R. (1996) The Internet an International Marketing. Sloan Management Review, 37(3), 60-75.

Saunders, R. (1999) Business the Amazon.com way, Capstone Publishing, Oxford.

Sparks, L. (1998) The Retail Logistics transformation, in Logistics and Retail Management, John Fernie and Leigh Sparks eds., Kogan Page, London.

Sterne, J. (1995) World Wide Web: Integrating the Internet into Your Marketing Strategy, John Wiley, New York.

The Economist (1998) Going Digital, 2nd edition, Profile Books, London.

Watson, R.T., Akselsen, S. and Pitt, L.F. (1998) Building Mountains in the flat landscape of the World Wide Web. California Management Review, 40(2), 36-56.

Watson, R.T. and Zinkham, G.M. (1997) Electronic commerce strategy: addressing the key questions. Journal of Strategic Marketing, 5(4), 189-209.

www.amazon.com

ww.tesco.co.uk 